\title{
Mengembangkan Kemampuan Penalaran Matematis Siswa Melalui Problem Centered Learning Pada Materi Peluang (Studi Eksperimen Di Kelas VIII SMP N 6 Singkawang)
}

\author{
Mariyam $^{1)}$ Rika Wahyuni ${ }^{2)}$ \\ ${ }^{1)}$ Prodi Pendidikan Matematika STKIP Singkawang \\ e-mail: mariyam.1804@yahoo.com \\ ${ }^{2)}$ Prodi Pendidikan Matematika STKIP Singkawang \\ e-mail: rikawahyuni33@yahoo.com
}

\begin{abstract}
Abstrak. Penelitian ini bertujuan untuk mengetahui kemampuan penalaran matematis siswa yang terbentuk setelah diterapkannya model Problem Centered Learning. Materi yang dipilih dalam penelitian ini adalah materi peluang yang ada di semester genap kelas VIII SMP. Secara rinci tujuan penelitian adalah untuk mengetahui: (1) kemampuan penalaran matematis siswa sebelum dan sesudah diterapkannya pembelajaran menggunakan PCL; (2) Mengetahui peningkatan kemampuan penalaran matematis siswa pada materi peluang yang mendapat pembelajaran matematika dengan menggunakan PCL; (3) Mendeskripsikanaktivitas siswa selama proses pembelajaran berlangsung dengan menggunakan PCL; (4) Mengetahui respon siswa terhadap diterapkannya PCL pada materi peluang.Penelitian ini menggunakan metode eksperimen dengan bentuk Pre-eksperimental design dengan rancangan one group pretest posttest. Hasil analisis data menunjukkan bahwa: (1) Kemampuan penalaran matematis siswa dilihat dari hasil posttest untuk setiap indikator kemampuan nilainya selalu bertambah tinggi dibandingkan nilai pretest nya; (2) Terdapat peningkatan kemampuan penalaran matematis siswa yang dilihat berdasarkan rata-rata keseluruhan hasil pretest dan posttest dengan nilai N-gain sebesar 0,553 (sedang); (3) pembelajaran menggunakan PCL dapat mengaktifkan siswa dengan persentase siswa berprilaku aktif selalu lebih besar dari siswa berprilaku pasif; (4) Respin siswa terhadap penerapan PCL dan soal-soal kemampuan penalaran yang diberikan adalah positif.
\end{abstract}

Kata Kunci: Kemampuan Penalaran Matematis, Problem Centered Learning.

\section{PENDAHULUAN}

Kemampuan penalaran tidak dapat lepas dari materi matematika. Kemampuan bernalar adalah satu di antara kompetensi matematika yang harus dicapai. Hal ini berkaitan dengan pengertian matematika yang secara etimologis diartikan sebagai ilmu yang diperoleh dengan bernalar, sehingga materi matematika dipahami melalui penalaran dan penalaran dipahami dan dilatih melalui belajar materi matematika [10]. [5] mengungkapkan bahwa kemampuan penalaran merupakan proses berfikir dalam penarikan kesimpulan. Sehingga diharapkan dengan kemampuan bernalarnya maka seseorang dimungkinkan untuk dapat memahami suatu konsep yang kemudian digunakan untuk memecahkan masalah. Sebagai konsekuensinya, berkaitan dengan kemampuan penalaran matematis tersebut sebagian besar pembelajaran di sekolah harus melibatkan penalaran
matematis.Kemampuan penalaran siswa tentang pelajaran yang diajarkan dapat terlihat dari sikap aktif, kreatif dan inovatif. Keaktifan siswa akan muncul jika guru memberikan kesempatan kepada siswa agar mau mengembangkan pola pikirnya, mau mengemukakan ide-ide. Apabila kemampuan penalaran tidak dikembangkan pada siswa, maka bagi siswa matematika hanya akan menjadi materi yang mengikuti serangkaian prosedur dan meniru contoh tanpa mengetahui maknanya, hal yang demikian menjadikan matematika sebagai suatu hal yang monoton, terurut dan bersifat prosedural.

Namun keadaan yang terjadi di lapangan belum sesuai dengan yang diharapkan. Berdasarkan observasi yang dilakukan di SMP Negeri 6 Singkawang ditemukan bahwa kegiatan pembelajaran yang sering dilakukan lebih difokuskan untuk melatih siswa terampil menjawab soal matematika, sedangkan kegiatan bernalar agar siswa menemukan sendiri solusi dari permasalahan tersebut belum dikembangkan. 
Akibatnya kemampuan penalaran matematis siswa terabaikan. Hal ini menjadi satu di antara faktor yang menyebabkan rendahnya kemampuan penalaran siswa dalam belajar matematika adalah karena pembelajaran yang didominasi oleh pendekatan ekspatansi, yaitu kegiatan pembelajaran yang terpusat pada guru.

Berdasarkan hasil studi Trends in International Mathematics and Science Study (TIMSS) menyebutkan bahwa rendahnya pencapaian kemampuan siswa Indonesia disebabkan oleh beberapa faktor diantaranya karena siswa di Indonesia kurang terlatih dalam menyelesaikan soal-soal kontektual, menuntut penalaran, argumentasi dan kreativitas dalam meyelesaikannya [6]. Lebih lanjut [10] menemukan bahwa satu di antara penyebab sejumlah siswa gagal menguasai dengan baik pokok-pokok bahasan dalam matematika yaitu siswa kurang memahami dan menggunakan nalar yang baik dalam menyelesaikan soal atau persoalan yang diberikan. Hal ini kerena dalam pembelajaran siswa lebih sering diberi soal-soal perhitungan dengan menggunakan algoritma yang ada tanpa adanya kebebasan dalam menjawab. Terkait beberapa temuan tersebut, terindentifikasi bahwa kesulitan siswa dalam memahami materi matematika karena kemampuan bernalarnya belum berkembang dengan baik, hal ini disebabkan oleh proses pembelajaran yang tidak mendukung atau memfasilitasi berkembangnya kemampuan tersebut.

Terkait dengan materi peluang, materi ini berisi pola-pola tertentu sehingga untuk memahaminya diperlukan penalaran. Untuk memudahkan siswa memahami materi tersebut diperlukan suatu pembelajaran yang mengarahkan siswa dalam bernalar sehingga diperoleh pemahaman yang utuh. Kondisi yang terjadi di lapangan adalah masih rendahnya kemampuan siswa dalam menyelesaikan soal-soal tentang peluang. Hal tersebut mengakibatkan rendahnya hasil belajar siswa pada materi tersebut. Sebagai solusi dari permasalahan tersebut, maka perlu dilakukan suatu perubahan pembelajaran yang mampu mengarahkan dan mengembangkan kemampuan penalaran matematis siswa. Selain itu, pembelajaran matematika juga seharusnya diarahkan untuk mengembangkan kebiasaan dan sikap belajar berkualitas yang tinggi.

Pembelajaran dengan PCL merupakan pembelajaran matematika yang dapat meningkatkan partisipasi dalam belajar dengan cara memberi kesempatan kepada siswa untuk melakukan aktivitas belajar. Menurut Jakubowski (1993) menyebutkan bahwa, PCL melibatkan siswa dalam akivitas-aktivitas yang potensial untuk menstimulasi siswa dalam berpikir dan membuat pengertian konsep matematika dengan cara mereka sendiri. Penelitian yang dilakukan oleh [3] menyebutkan bahwa pembelajaran Problem Centered Learning (PCL) dilaksanakan dengan baik sehingga berdampak pada meningkatnya kemampuan siswa. [3] menunjukkan bahwa PCL dapat mengaktifkan siswa sehingga hal tersebut berkontribusi pada meningkatnya ketuntasan hasil belajar siswa. Sedangkan hasil penelitian [8] juga menunjukkan bahwa siswa yang mendapat pembeajaran dengan PCL peningkatan kemampuan pemecahan masalahanya cenderung lebih baik dibandingkan siswa yang mendapat pembelajaran dengan pembelajaran konvensional. Dengan demikian, mengingat pentingnya kemampuan penalaran matematis dalam pembelajaran matematika, guru diharapkan dapat merencanakan pembelajaran dengan Problem Centered Learning (PCL). Pembelajaran PCL didugadapat meningkatkan kemampuan penalaran matematika siswa. Selain meningkatkan kemampuan penalaan matematis siswa, pemeblejaran PCL diharapkan dapat meningkatakan aktivitas siswa dan respon siswa terhadap pembelajaran matematika tergolong positif.

\section{METODE}

Bentuk penelitian yang digunakan dalam penelitian ini adalah Pre-Experimental Designs (nondesigns) dengan menggunakan rancangan penelitian yang one group pretest posttest yaitu rancangan yang menggunakan satu kelompok sampel dimana siswa diberikan tes awal sebelum diberikan perlakuan, perlakuan, dan setelah itu 
diberikan tes akhir untuk mengetahui hasil belajar siswa setelah diberikannya perlakuan. Rancangan ini dapat diperjelas sebagai berikut:

Populasi dalam penelitian ini adalah seluruh siswa kelas VIII SMP Negeri 6 Singkawang.Teknik pengambilan sampel yang digunakan adalah teknik purposive samplingyaitu teknik pengambilan sampel dari populasi yang dilakukan karna pertimbangan tertentu [7]. Berdasarkan pertimbangan oleh pihak sekolah terpilihlah kelas VIII D sebagai sampel penelitian, karena di kelas tersebut guru yang mengajar mata pelajaran matematika berhalangan hadir karena ada pelatihan dan materi peluang sebagai materi akhir di semester genap belum diajarkan.

Teknik dan instrumen pengumpul data yang digunakan dalam penelitian ini adalah: (1) teknik pengukuran yang digunakan untuk mengetahui kemampuan pemalaran matematis siswa pada materi peluang dengan cara memberikan tes kepada siswa berupa soal esay yang memuat tiga indikator kemampuan penalaran yaitu memeriksa validitas argumen dan menarik kesimpualn logis; meberikan penjelasan terhadap hubungan atau pola yang ada; dan menggunakan pola hubungan untuk menganalisis sesuatu atau membuat strategi; (2) teknik observasi langsung yang digunakan untuk mengetahui aktivitas siswa selama proses pembelajaran berlangsung dengan menggunakan lembar pengamatan aktivitas; (3) teknik komunikasi tak langsung yang digunakan untuk mengetahui respon siswa setelah diterapkannya pembelajaran PCL dengan menggunakan angket respon yang berisi peryantaan tentang skala sikaf siswa terhadap pembelajaran dan terhadap soalsoal yang digunakan.

Hasil yang diperoleh dari ketiga instrumen tersebut selanjutnya dianalisis untuk menjawab rumusan masalah penelitian. Intrumen tes digunakan untuk mengetahui kemampuan penalaran matematis yang diperoleh siswa, yang kemudian dideksripsikan berdasarkan pedoman penskoran kemampuan penalaran yang menggunakan rating scale 0-4. Dari hasil tes tersebut juga dilihat peningkatan kemampuan yang diperoleh siswa dengan menggunakan rumus $\mathrm{N}$-gain yang dibagi ke dalam tiga kriteria (Tinggi, sedang dan rendah). Lembar pengamatan aktivitas terdiri dari pernyataan yang mengamati siswa berdasarkan dua perilaku (aktif dan pasif) yang hasilnya kemudian dianalisis menggunakan rumus persentasi siswa yaitu T_s=X_i $/ \mathrm{N} \times 100 \%$ dan ditafsirkan berdasarkan tabel berikut:

Tabel 1

Tafsiran Harga Persentase Sebaran Siswa

\begin{tabular}{ccc}
\hline $\begin{array}{c}\text { No } \\
.\end{array}$ & Nilai $(\boldsymbol{\%})$ & Kriteria \\
\hline 1. & 0 & Tidak ada \\
\hline 2. & $1-25$ & Sebagian Kecil \\
\hline 3. & $26-49$ & Hampir Separuhnya \\
\hline 4. & 50 & Separuhnya \\
\hline 5. & $51-79$ & Sebagian besar \\
\hline 6. & $80-99$ & Hampir seluruhnya \\
\hline 7. & 100 & Seluruhnya \\
\hline & & Koentjaraningrat [2]
\end{tabular}

Lembar angket respon berisi pernyatan positif dan negatif dengan empat kategori jawaban yaitu Sangat Setuju (SS), Setuju (S), Tidak Setuju (TS), dan Sangat Tidak Setuju (STS) yang kemudian hasilmya dianalisis menggunakan rumus: Persen Siswa $=$ dan ditafsirkan berdasarkan Tabel berikut :

Tabel 2.

Kriteria Respon Siswa

\begin{tabular}{ccc}
\hline No & Nilai $(\boldsymbol{\%})$ & Kriteria \\
\hline 1. & $25 \leq$ Respon $\leq 43,75$ & Sangat Tidak Baik \\
\hline 2. & $43,75<$ Respon $\leq 62,50$ & Tidak Baik \\
\hline 3. & $62,50<$ Respon $\leq 81,25$ & Baik \\
\hline 4. & $81,25<$ Respon $\leq 100$ & Sangat Baik \\
\hline
\end{tabular}

Modifikasi [1]

\section{HASIL DAN PEMBAHASAN}

Hasil penelitian ini berisi tentang temuantemuan selama penelitian berlangsung. Temuan yang diperoleh meliputi data tentang kemampuan penalaran matematis, data aktivitas siswa dan data respon siswa.

\section{a. Kemampuan Penalaran Matematis}

Data hasil tes kemampuan penalaran matematis diperoleh melalui tes tertulis berbentuk uraian sebanyak 3 butir soal, dengan masing- 
masing soal memiliki skor maksimum 4. Masingmasing soal mengandung indikator kemampuan penalaran matematis siswa yang pada penelitian ini diukur dari tiga aspek, yaitu: (1) Memeriksa validitas argumen dan menarik kesimpulan logis; (2) Memberi penjelasan terhadap model, fakta, sifat, hubungan, atau pola yang ada; dan (3) Menggunakan pola hubungan untuk menganalisis situasi atau membuat analogi. Hasil pretest dan postest kemampuan penalaran matemats siswa disajikan pada Diagram Batang 1 berikut:

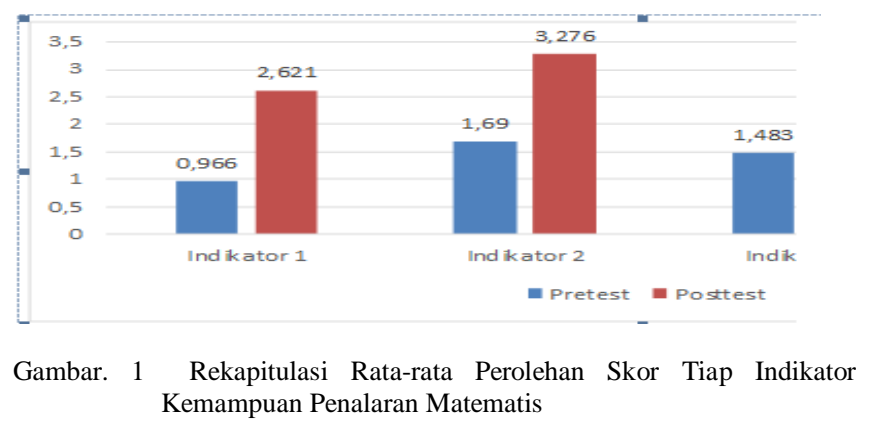

Dari Diagram Batang 1 tampak bahwa rata-rata perolehan skor posttest kemampuan penalaran matematis siswa untuk setiap indikator selalu lebih tinggi dibandingkan dengan rata-rata perolehan skor pretest kemampuan penalaran matematis siswa. Selanjutnya untuk melihat seberapa besar peningkatan kemampuan penalaran matematis siswa beserta ketegorinya, maka dari hasil pretest dan hasil posttest akan dihitung nilai gain ternormalisasi (N-gain). Gain ternormalisasi merupakan selisih antara nilai pretest dan posttest untuk mengukur peningkatan kemampuan penalaran matematis siswa. Dari 29 siswa dapat dihitung jumlah siswa yang nilai $N$ gain nya berada pada kategori tinggi, sedang dan rendah. Berikut disajikan dalam Diagram Batang 2 jumlah siswa untuk setiap kategori $N$-gain

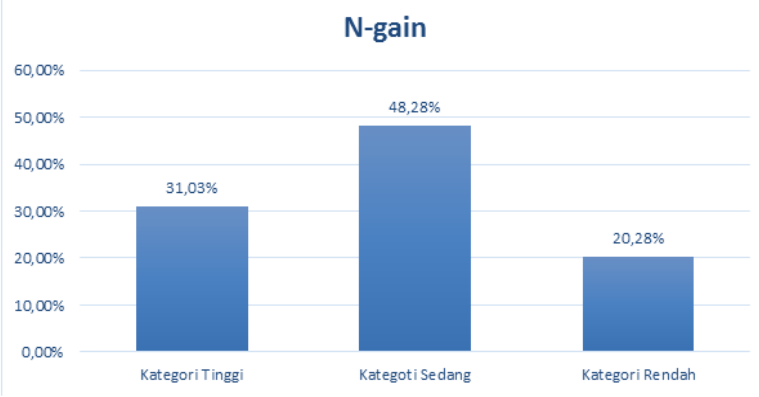

Gambar 2. Persentase Jumlah Siswa Untuk Setiap Kategori N-Gaiin Kemampuan Penalaran Matematis

Berdasarkan hasil penelitian tersebut diketahui bahwa untuk setiap indikator kemampuan penalaran matematis siswa dilihat dari hasil posttest nilainya selalu lebih tinggi bila dibandingkan dengan hasil pretest nya. Hal ini menunjukkan bahwa dengan diberikannya pembelajaran menggunakan PCL dapat meningkatkan kemampuan siswa, khususnya kemampuan penalaran. Hal ini diduga karena selama pembelajaran dengan PCL siswa diarahkan untuk memecahkan permasalahan yang diberikan dalam bentuk LKS menggunakan penalaran mereka. Pertanyaan-pertanyaan yang ada di dalam LKS diarahkan sesuai dengan indikator kemampuan penalaran.Dengan adanya peningkatan kemampuan penalaran matematis siswa menunjukkan bahwa pembelajaran dengan PCL berkontribusi terhadap kemampuan siswa. Hal ini sesuai dengan ciri khusus PCL sebagai aktivitas pembelajaran yang menyebutkan bahwa PCL memfokuskan pada proses-proses penyelidikan dan penalaran dalam pemecahan masalah sehingga mendapatkan hasil-hasil eksperimen yang benar atau jawaban yang benar terhadap suatu pertanyaan masalah [4].

\section{b. Aktivitas Siswa Selama Diterapkannya PCL}

Data aktivitas siswa dalam penelitian ini diperoleh melalui kegiatan observasi yang dilakukan oleh dua orang observer/pengamat pada setiap pertemuan atau tatap muka. Kegiatan pengamatan dilakukan selama proses pembelajaran berlangsung dimulai dari awal pembelajaran hingga akhir pembelajaran dengan dipandu lembar pengamatan aktivitas yang terdiri dari enam aspek pengamatan aktivitas dengan 
setiap aspek mengandung dua indikator untuk perilaku aktif dan satu indikator perilaku pasif.

Proses pembelajaran berlangsung dengan menerapkan PCL yang dilaksanakan sebanyak dua kali pertemuan. Dari hasil pengamatan diketahui bahwa terjadi peningkatan jumlah prilaku aktif siswa pada pertemuan kedua untuk setiap aspek. Untuk lebih jelasnya hasil akhir pengamatan tersebut disajikan pada Diagram Batang 3. Berdasarkan Diagram Batang 3 memperlihatkan bahwa rata-rata persentase jumlah sebaran siswa untuk kategori perilaku aktif siswa pada setiap aspek pengamatan aktivitas selalu lebih tinggi dibandingkan rata-rata persentase jumlah sebaran siswa untuk kategori perilaku pasif. Hal ini memperlihatkan bahwa aktivitas siswa selama diterapkannya PCL tergolong baik.

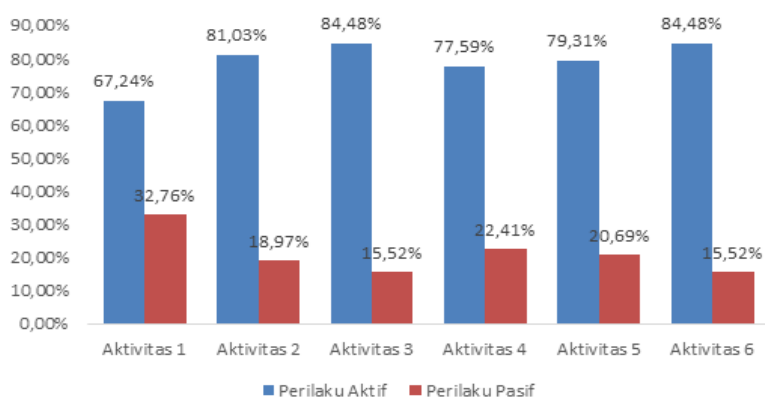

Gambar 3. Rata-rata Persentase Jumlah sebaran Siswa untuk Setiap Aspek Pengamatan Aktivitas Siswa

Berdasarkan aktivitas siswa memperlihatkan adanya peningkatan kualitas aktivitas siswa pada setiap aspek kegiatan, terutama pada aspek kegiatan yang ada kaitannya dengan pembelajaran PCL yaitu aspek pengamatan sikap pada kegiatan inti pembelajaran yang berada pada indikator kedua, ketiga, keempat dan kelima. Pada ketiga aspek tersebut tampak persentase perolehan sebaran siswa yang tergolong tinggi. Dalam proses pembelajaran, ketika diberikan soal-soal dalam bentuk LKS yang meminta siswa untuk mengerjakan secara pribadi tampak bahwa sangat antusias, siswa berusaha sungguh-sungguh dalam memahami masalah yang ada dan berfikir untuk menyelesaikannya. Kemudian siswa juga sangat berkonsentrasi mendengarkan penjelasan guru. Selain itu ketika siswa dikelompokkan untuk berdiskusi untuk mencocokkan jawaban yang telah diselesaikannya secara mandiri siswa sangat bersemangat dan siswa juga terlibat aktif dalam kegiatan diskusi kelas untuk saling berbagi (sharing). Secara keseluruhan diperoleh rata-rata persentase sebaran siswa sebesar $79,02 \%$ yang artinya sebagian besar siswa berprilaku sesuai dengan aspek yang diamati.Sedangkan untuk kebalikannya yaitu untuk kategori yang berperilaku pasif dengan indikator berprilaku yang tidak relevan dengan KBM yang diamati pada setiap aspek kegiatan, rata-rata persentase jumlah sebaran siswa untuk indikator tersebut adalah 20,98\% yang artinya hanya sebagian kecil siswa yang berprilaku tidak positif. Hal ini menunjukkan bahwa aktivitas siswa dengan diterapkannya PCL tergolong positif. Penurunan kualitas perilaku pasif sepanjang rangkaian pembelajaran, menunjukkan sikap siswa semakin membaik atau positif terhadap terhadap kegiatan belajar mengajar [8]. Hasil penelitian [8] diperoleh bahwa keseluruhan aktivitas positif siswa terhadap proses pembelajaran dengan pendekatan PCL menunjukan peningkatan pada setiap pertemuan.

\section{c. Respon Siswa Terhadap Penerapan PCL}

Data yang diperoleh adalah respon/tanggapan siswa terhadap skala sikap yang digunakan untuk mengetahui sikap siswa terhadap pembelajaran dan skala sikap hanya diberikan terhadap kelas eksperimen. Sikap siswa yang dianalisis meliputi: sikap siswa terhadap pembelajaran dengan PCL dan sikap siswa terhadap soal-soal penalaran. Angket skala sikap yang diberikan berisi 15 pernyataan yang terdiri dari 10 pernyataan yang meminta tanggapan siswa terhadap penerapan PCL dan 5 pernyataan yang meminta tanggapan siswa tentang soal-soal kemampuan penalaran matematis. Berikut disajikan rekapitulasi hasil perhitungan respon siswa pada Tabel 3 berikut:

Tabel 3.

Rekapitulasi Hasil Perhitungan Respon Siswa Terhadap Angket Skala Sikap

\begin{tabular}{|c|c|c|c|c|c|}
\hline \multirow[t]{2}{*}{ Pernyataan } & \multicolumn{2}{|c|}{ Jawaban } & \multicolumn{3}{|c|}{ Jlh } \\
\hline & SS & $S$ & TS & STS & \\
\hline $\begin{array}{l}\text { Belajar dengan (PCL)sangat } \\
\text { menyenangkan dan menuntut } \\
\text { kreativitas saya. }\end{array}$ & & & & & \\
\hline & 12 & 15 & 2 & 0 & 97 \\
\hline
\end{tabular}




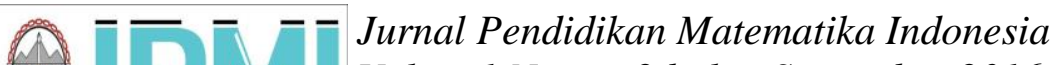 \\ Volum 1 Nomor 2 bulan September 2016. Halaman 74-80 \\ p-ISSN: 2477-5967 e-ISSN: 2477-8443}

\begin{tabular}{|c|c|c|c|c|c|}
\hline \multirow[t]{2}{*}{ Pernyataan } & \multicolumn{2}{|c|}{ Jawaban } & \multicolumn{3}{|c|}{ Jlh } \\
\hline & SS & $S$ & TS & STS & \\
\hline $\begin{array}{l}\text { Cara guru membawakan } \\
\text { pelajaran matematika di kelas } \\
\text { membuat saya kurang senang } \\
\text { dan membingungkan }\end{array}$ & 0 & 0 & 16 & 13 & 100 \\
\hline $\begin{array}{l}\text { Pembelajaran secara mandiri } \\
\text { menuntut saya untuk berfikir } \\
\text { memahami permasalahan yang } \\
\text { diberikan dalam LKS }\end{array}$ & 10 & 17 & 1 & 1 & 94 \\
\hline $\begin{array}{l}\text { Belajar melalui kelompok } \\
\text { menumbuhkan sikap saling } \\
\text { mengoreksi dan menumbuhkan } \\
\text { semangat bekerja sama }\end{array}$ & 6 & 18 & 3 & 2 & 86 \\
\hline $\begin{array}{l}\text { Belajar dalam kelompok kurang } \\
\text { menumbuhkan pendalaman } \\
\text { materi pelajaran karena belajar } \\
\text { kelompok membuat saya punya } \\
\text { kesempatan bergurau }\end{array}$ & 1 & 4 & 18 & 6 & 87 \\
\hline $\begin{array}{l}\text { Diskusi kelas dalam penerapan } \\
\text { PCL menumbuhkan semangat } \\
\text { saya dalam belajar karena berisi } \\
\text { kesempatan untuk saling berbagi } \\
\text { (sharing) }\end{array}$ & 10 & 15 & 3 & 1 & 92 \\
\hline $\begin{array}{l}\text { Presentasi di depan kelas } \\
\text { membuat saya gugup }\end{array}$ & 4 & 5 & 10 & 10 & 84 \\
\hline $\begin{array}{lcr}\text { Pembelajaran } & \text { dengan } & \text { PCL } \\
\text { melatih saya } & \text { untuk berani } \\
\text { mengemukakan } & \text { pendapat di } \\
\text { depan kelas } & & \end{array}$ & 9 & 10 & 7 & 3 & 83 \\
\hline $\begin{array}{l}\text { Belajar kelompok memerlukan } \\
\text { banyak waktu sehingga waktu } \\
\text { untuk memahami materi terbuang } \\
\text { sia-sia. }\end{array}$ & 4 & 4 & 12 & 9 & 84 \\
\hline $\begin{array}{l}\text { Pembelajaran dengan PCL } \\
\text { kurang memberikan manfaat bagi } \\
\text { saya, sehingga tidak membantu } \\
\text { saya dalam memahami materi } \\
\text { peluang }\end{array}$ & 0 & 3 & 16 & 10 & 94 \\
\hline $\begin{array}{llr}\text { Soal-soal yang } & \text { diberikan } & \text { oleh } \\
\text { guru dalam bentuk } & \text { tes } \\
\text { memotivasi } & \text { saya } & \text { untuk } \\
\text { menyelesaikannya } & \end{array}$ & 12 & 15 & 2 & 0 & 97 \\
\hline $\begin{array}{lrr}\text { Soal-soal yang dalam } & \text { LKS } \\
\text { melatih saya } & \text { untuk } \\
\text { menyelesaikannya } & \text { dan } \\
\text { memudahkan saya untuk } & \text { memahami materi peluang. }\end{array}$ & 15 & 14 & 0 & 0 & 102 \\
\hline $\begin{array}{l}\text { Bahasa yang digunakan dalam } \\
\text { soal membingungkan sehingga } \\
\text { saya kesulitan dalam menemukan } \\
\text { jawabannya. }\end{array}$ & 0 & 0 & 17 & 12 & 99 \\
\hline $\begin{array}{l}\text { Soal-soal yang diberikan } \\
\text { membuat saya merasa kalau } \\
\text { matematika itu menyenangkan } \\
\text { dan memotivasi saya untuk lebih } \\
\text { bersungguh-sungguh dalam } \\
\text { belajar. }\end{array}$ & 10 & 17 & 2 & 0 & 95 \\
\hline $\begin{array}{l}\text { Soel-soal yang diberikan tidak } \\
\text { memberikan manfaat bagi } \\
\text { pengetahuan saya }\end{array}$ & 0 & 3 & 15 & 11 & 95 \\
\hline Rata-rata Jumlah & & & & & \\
\hline
\end{tabular}

Jika dilihat dari keseluruhan baik itu sikap siswa terhadap pembelajaran dengan PCL maupun sikap siswa terhadap soal-soal penalaran diperoleh rata-rata persentase sebesar $79,83 \%$ yang artinya respon siswa berada dalam kriteria baik.
Berdasarkan respon siswa terhadap angket skala sikap yang terdiri dari dua aspek sikap yaitu aspek sikap siswa terhadap pembelajaran menggunakan PCL dan sikap siswa terhadap soal-soal kemampuan penalaran diperoleh bahwa untuk setiap indikator pernyataan positif misalnya tentang kesukaan siswa terhadap pembelajaran PCL, kesukaan siswa tehadap soal-soal yang diberikan selalu disikapi siswa secara positif, dimana diperoleh rata-rata persentase kesetujuan sebesar $80,39 \%$ yang berada dalam kriteria baik. Sedangkan jika dilihat dari respon siswa untuk pernyataan negatif terhadap dua skala sikap juga selalu disikapi siswa secara positif, dimana diperoleh rata-rata persentase ketidaksetujuan sebesar 79,19\% yang berada dalam kriteria baik. Ini artinya siswa cenderung merasa tidak setuju terhadap penyataan negatif tentang pembelajaran PCL maupun tentang soal-soal yang diberikan. Diperolehnya respon yang positif dapat berkontribusi terhadap keberhasilan pembelajaran. [8] menyatakan bahwa awal keberhasilan siswa dalam belajar jika siswa berminat terhadap pembelajaran dan minat memiliki pengaruh positif terhadap kualitas pembelajaran yang terjadi dalam diri siswa yang dapat diketahui melalui pengolahan skor sikap yang didata berdasarkan respon siswa terhadap skala sikap.

\section{IV.KESIMPULAN DAN SARAN}

\section{KESIMPULAN}

Berdasarkan hasil penelitian dan pembahasan dapat disimpulkan bahwa pembelajaran dengan PCL dapat mengembangkan kemampuan penalaran matematis siswa karena kemampuan penalaran matematis siswa dilihat dari hasil posttest untuk setiap indikator kemampuan nilainya selalu bertambah tinggi dibandingkan nilai pretest nya dan terdapat peningkatan kemampuan penelaran matematis siswa yang dilihat berdasarkan rata-rata keseluruhan hasil pretest dan posttest dengan nilai $N$-gain sebesar 0,553 yang berda dalam kategori sedang. Pembelajaran menggunakan PCL juga dapat mengaktifkan siswa dengan persentase siswa berprilaku aktif selalu lebih besar dari siswa 
berperilaku pasif dalam setiap aspek pengamatannya yaitu diperoleh rata-rata rekapitulasi untuk persentase sebaran siswa berprilaku aktif sebesar 79,02\% (sebagian besar) dan rata-rata rekapitulasi untuk persentase sebaran siswa berprilaku pasif sebesar 20,98 (sebagian kecil). Selanjutnya respon siswa terhadap penerapan PCL dan soal-soal kemampuan penalaran yang diberikan adalah positif dengan persentase kesetujuan terhadap pernyataan positif sebesar 80,39\% (Sangat Setuju) dan persentase tingkat ketidaksetujuan terhadap pernyataan negatif sebesar 79,19\% (Tidak Setuju).

\section{Saran}

Secara keseluruhan pembelajaran dengan menggunakan PCL dapat mengebangkan kemampuan siswa khuunya kemampuan penalaran matematis. Namun dalam pelaksanaannya ada bebrapa hal yang perlu diperhatikan, misalnya: 1) Sebelum melaksanakan pembelajaran menggunakan PCL sebaiknya guru perlu merancang dan mempersiapkan apa saja yang diperlukan sehingga pelaksanaan setiap tahapan pembelajaran terlaksana dengan baik; 2) Siswa perlu diarahkan dan dibimbing dalam pelaksanaan pembelajaran; 3) Pemberian soal-soal sebaiknya dibuat lebih dari 1 soal untuk setiap indikator agar lebih menunjukkan ketercapaian kemampuan siswa; 4) Pernyataan pada angket respon siswa benar-benar menunjukkan atau mewakili informasi yang ingin diperoleh dari siswa terhadap perlakuan yang diberikan sehingga hasil yang diperoleh dapat dijadikan acuan dalam melakukan penelitian selanjutnya. Sedangkan untuk beberapa peneliti lainnya, hal-hal yang perlu diperhatikan adalah mempertahankan prestasi belajar siswa dengan mempertahankan pemberian perlakuan yang membuat siswa antusias dalam belajar dan mengkaji kesulitankesulitan siswa terutama siswa yang memperoleh nilai cukup rendah pada materi peluang.

\section{DAFTAR PUSTAKA}

[1] Arikunto, Suharsimi. (2010). Manajemen Penelitian, Jakarta: Rineka Cipta.

[2] Mantili, Elvira DS. (2010). Implikasi Pendekatan STM terhadap keterampilan Proses Sains dan hasil Belajar Siswa Dalam Pelajaran Pencemaran Air di Kelas VIISMPPertiwi Pontianak.Universitas Tanjung Pura Pontianak.

[3] Imamah. (2014). Penerapan Model Pembelajaran Problem Centered Learning (PCL) untuk Meningkatkan Hasil Belajar SiswaSub Pokok Bahasan Operasi Hitung Bentuk Aljabar Kelas VII A Semester Ganjil di SMP Negeri 14 Jember Tahun Ajaran 2013/2014. Jember: Skripsi Universitas Jember.

[4] Jakubowski, E. (1993). "Constructing Potential learning Opportunities in Middle Grades Mathematics". Tobin, K. (Ed.). The Practice of Constructivism in Science Education. New Jersey: Lawrence Erlbaum Associates, inc. p. 135-144.

[5] Permana, Yanto dan Sumarmo, Utari. (2007). "Mengembangkan Kemampuan Penalaran dan Koneksi Matematika Siswa SMA Melalui Pembelajaran Berbasis Masalah". Jurnal Education UPI Vol. 1 No. 2, pp. 116-123.Sumarmo. 2013. Berfikir dan Disposisi Matematik Serta Pembelajarannya. Bandung: Kumpulan Makalah (Jurnal Penelitian)

[6] Setiadi, Hari, dkk. (2012). Kemampuan Matematika Siswa SMP Di Indonesia. Jakarta: Puspendik.

[7] Sugiyono, (2009). Metode Penelitian Kuantitatif Kualitatif dan R\&D, Bandung: Alfabeta.

[8] Suhendri. (2006). Penerapan Model Pembelajaran Problem Centered Learning (PCL) untuk Meningkatkan Hasil Belajar SiswaSub Pokok Bahasan Operasi Hitung Bentuk Aljabar Kelas VII A Semester Ganjil di SMP Negeri 14 Jember Tahun Ajaran 2013/2014. Bandung: Tesis Universitas Pendidikan Bandung (UPI).

[9] Suherman, E. 2003. Strategi Pembelajaran Matematika Kontemporer. Bandung: UPI-JICA

[10] Wahyudin. (1999). Kemampuan Guru Matematika, Calon Guru Matematika, dan Siswa dalam Pelajaran Matematika (Disertasi). Bandung: IKIP Bandung. 